\title{
Equine metabolic syndrome in Colombian creole horse: case report
}

\author{
[Síndrome metabólica equina em cavalo crioulo Colombiano:relato de caso]
}

\author{
C.A. Castillo, C. Jaramillo, M.J. Loaiza, R. Blanco
}

\author{
Faculty of Administrative and Agricultural Sciences - Corporación Universitaria Lasallista- Caldas, \\ Antioquia-Colombia. Carrera 51118 sur 57
}

\begin{abstract}
The equine metabolic syndrome is a condition that can be recognized because of obesity, insulin resistance and laminitis. Genetic factors could play a role in the occurrence of this syndrome. Certain breeds such as ponies (including the South American creole horses) have a lower sensibility to insulin and a higher prevalence of hyperinsulinemia. The environment and management conditions, such as overfeeding and lack of exercise are factors that bring a propensity for obesity. The adipose tissue works as an endocrine organ producing hormones (adipokines or adipocytokines) that affect the horse's metabolism. The objective of this report is to describe the first case report of a Colombian creole mare with a metabolic syndrome, diagnosed by means of the combined test of glucose-insulin and clinical signs. Early diagnosis of this entity and an adequate treatment are useful for improving the life and the zootechnical conditions of the patient.
\end{abstract}

Keywords: equine, insulin resistance, obesity, laminitis

\section{RESUMO}

A síndrome metabólica equina é uma alteração reconhecida por apresentar obesidade, resistência à insulina e laminite. Fatores genéticos poderiam ser relevantes na ocorrência dessa síndrome, em que certas raças consideradas pôneis (incluídas as raças crioulas de cavalos sul-americanos) têm mais baixa sensibilidade à insulina e mais alta prevalência de apresentar hiperinsulinemia. As condições ambientais $e$ de manejo, como superalimentação e falta de exercício, são fatores predisponentes para o desenvolvimento da obesidade. O tecido adiposo cumpre atividades como um órgão endócrino produtor de hormônios (adipocinas ou adipocitocinas) que afetam o metabolismo do cavalo. $O$ objetivo deste relatório é descrever o primeiro registro de caso de uma égua de raça Cavalo Crioulo Colombiano (CCC) com síndrome metabólica, diagnosticada pela prova combinada de glicose-insulina e por quadro clínico. $O$ diagnóstico precoce desta entidade e seu tratamento adequado permitem melhorar as condições de vida e zootécnicas do paciente que dela padece.

Palavras-chave: equino, resistência à insulina, obesidade, laminite

\section{INTRODUCTION}

Equine metabolic syndrome (EMS) is a condition introduced in veterinary medicine for the first time in 2002 by Johnson, who proposed that obesity, resistance to insulin (IR) and laminitis were the components of a clinical syndrome recognized in horses and ponies (Frank, 2009; Frank, 2011) and such condition was previously associated to hyperthyroidism (Freestone et al., 1992). The name comes from human medicine, where metabolic syndrome (MetS) refers to a series of factors that increase risk of cardiovascular diseases, including obesity, intolerance to glucose, IR, dyslipidemia, microalbuminuria and hypertension (Frank, 2011). For equines, practitioners use clinical signs, despite their poor specificity, finding an excessive obesity or located adiposity, resistance to insulin and old or new episodes of laminitis (Bertin and Sojka-Kritchevsky, 2013; Marycz et al., 2014).

Recebido em 27 de julho de 2016

Aceito em 23 de setembro de 2016

E-mail: cricastillo@lasallistadocentes.edu.co 
Genetic factors could play a central role in the EMS cases, as certain breeds seem to have a higher propensity to develop this condition. Some breeds have higher prevalence, such as: Welsh and Dartmoor ponies, Morgans, Tennesee Walking, Saddlebreds, Arabian and Paso Fino. The equines affected have a high metabolic efficiency, which means a lower need of calories to maintain their body weights if compared to unaffected animals (Geor et al., 2013).

There are postulates concerning certain genetic mutations, under the "saving genes" concept, and the melanocortin 4 receptor gene is a possible candidate. This gene is responsible for food consumption, sensibility to insulin and adiposity (Frank, 2011). In general, horses considered to be ponies (including most of the South American creole breeds) have a lower sensibility to insulin and a higher prevalence for having hyperinsulinemia if compared to other equine breeds (Geor et al., 2013), but the environmental and management conditions of the equines have changed in recent years with factors such as overfeeding and lack of exercise, which predisposes to the development of obesity (Frank, 2011).

Obesity in animals affected by EMS is easy to evaluate, especially adiposity located in the neck, which is known as "neck crest". For the different degrees of adiposity in this region, Carter et al. developed a ranking between 0 and 5 according to the degree of adiposity found, in which animals with EMS have a degree of 3 or above ("enlarged and thick crest in the middle part of the neck, and it looks like a mountain") (Carter, 2009).

There are other zones of the body where located adiposity deposits can be found, like the base of the tail, the back of the shoulder, the foreskin and the mammary gland (Frank, 2009; Frank, 2011; Geor et al., 2013).

Adipose tissue also works as an endocrine organ, producing hormones (adipokines or adipocytokines) (Caselli, 2014), and a malfunction of this tissue due to a reduction of the tissue perfusion produced by obesity is a pathophysiological important characteristic found in humans with MetS, and it finally produces IR, systemic inflammation, hypertension and a prothrombotic state.
Insulin is an anabolic hormone responsible for adequate development of tissues, cellular growth and maintenance of glucose homeostasis. It is secreted by pancreas $\beta$ cells in response to increases of glucose and amino acids in the blood, after food is consumed. It regulates metabolism in several ways, such as reducing hepatic production of glucose and increasing the amount of glucose in skeletal muscles and the adipose tissue. It also affects lipid metabolism by increasing lipid synthesis in the liver and fat cells, and reducing free fatty acids from the adipose tissue. GLUT4 is the isoform of glucose transportation that is more sensible to insulin's action in the tissues, and can be found especially in the muscles and adipose tissue. A defect in the expression or in the function of GLUT4 can be the cause of IR, too (Sesti, 2006).

Animals affected by EMS have an IR that comes along with hyperinsulinemia, and this fact is used as a diagnosis method in which the values on an empty stomach above $20 \mathrm{mIU} / \mathrm{L}$ indicate EMS. The IR of animals with EMS would be a reason to suspect an elevated glycemia (Geor et al., 2013).

EMS is associated to important disturbance in equines, such as laminitis (Frank, 2009; Burns et al., 2010; Bertin and Sojka-Kritchevsky, 2013), in which old and new episodes can take place. It has been demonstrated that IR with hyperinsulinemia is a factor that predisposes the possible development of laminitis in equines. Insulin usually acts as a slow vasodilator, increasing the distribution of blood in the muscles (when glucose is abundant), this is due to the increase of the synthesis of nitric oxide in the endothelium when it is stimulated by insulin. Another factor that is involved in the development of laminitis would be the glucotoxicity produced by hyperglycemia, which, added to the expression of adhesion molecules in the endothelial surface, would worsen the condition (Frank, 2009).

In obesity with resistance to insulin, adiponectin and its receptor are reduced in their regulation, and this leads to the activation of the signage ways involved with the regulation of metabolism, and this is a therapeutic strategy that can be approached for obesity and IR (Caselli, 2014). 
The TNF- $\alpha$ boosts the development of IR in humans in the hypothalamus or adipocytes, where it has been determined that TNF- $\alpha$ concentrations in serum of equines with EMS and IR have higher values if compared to those of healthy animals, thus leading to something similar with its expression in the adipose tissue and demonstrating the importance of TNF- $\alpha$ in EMS (Marycz et al., 2014).

IR can be caused by a reduction in the function of the insulin receptor, a reduction of the pancreatic secretion of insulin in response to a load of glucose or a combination of both, in which disturbances in the stages of the insulin's signage way could be involved (Bertin y SojkaKritchevsky, 2013). This way, the disturbance can be found at the same insulin receptor where two isoforms are reported in humans, each one with a different sensibility to the ligand (Sesti, 2006).

For diagnosis of EMS there must be good anamnesis and a physical evaluation (appearance of the patient, obesity, located adiposity and laminitis) according to the experience of the clinical professional, the use of laboratory aids to determine glucose concentrations in the blood (above $110 \mathrm{mg} / \mathrm{dL}$ in EMS, on an empty stomach) or insulin concentrations in the blood above $20 \mu \mathrm{IU} / \mathrm{mL}$ in EMS, on an empty stomach) will be required. These are not, however, specific methods to perform a diagnosis (Frank, 2009; Frank, 2011), specific tests can be used, such as the combined test of glucose and insulin, in which the animal is not fed the night before and the next morning is given dextrose at $50 \%(150 \mathrm{mg} / \mathrm{kg} / \mathrm{IV})$, followed by a single dose on insulin $(0.1 \mathrm{IU} / \mathrm{kg} / \mathrm{IV})$. Then blood samples are collected at $0,1,5,15,25,35,45,60,75,90,105,120,135$ and 150 minutes to measure glucose and at 0 and 45 minutes to measure insulin, a horse with EMS maintains the glucose concentration after 45 minutes with values above $100 \mu \mathrm{IU} / \mathrm{mL}$. Another good test is oral glucose test, in which the animal is not fed the night before and in the morning is given oral dextrose $(150 \mathrm{mg} / \mathrm{kg})$ or corn syrup $(15 \mathrm{~mL} / 100 \mathrm{~kg})$, collecting blood samples for insulin concentration after 60 and 90 minutes, in which the patient with EMS will have insulin concentrations above $60 \mu \mathrm{IU} / \mathrm{mL}$ in any of the measurements. Oral glucose test is most common currently, given its simplicity and low cost, demonstrating a high correlation with the combined glucose and insulin test in animals with EMS (Frank, 2011).

Within the treatment, one of the main measurements is the weight loss, reducing access to carbohydrates and an increase of the physical activity. However, as the animal is affected by laminitis, it cannot be subjected to physical work and will also require a pharmacological therapy. Levothyroxine sodium is currently being used, because it reduces the animal's weight and increases the sensibility to insulin. Metformin is another drug that increases the sensibility to insulin, suppresses the production of hepatic glucose and also increases the quantity of GLUT4 in the cell's membranes of the skeletal muscles, but this has only been demonstrated in humans. Pioglitazone has had better results in equines, because it increases the mRNA expression of the insulin receptor in the skeletal muscles (Frank, 2011). There is not, however, a pharmacologically efficient treatment yet, due to the fact that the pathophysiological conditions of humans and equines are different.

\section{Approach}

At the Veterinary Clínic of the Corporación Universitaria Lasallista a Colombian creole mare was received, with an eight months old female filly, still lactating. The obesity of the mother was pronounced, so it was approached in order to determine the cause and in the physical examination, the following aspects were found: body condition 8/9, weight: 356 kilos, neck adiposity: 4, according to Carter et al.; adiposity in mammary gland, tail base and concentric rings of the hooves of forelimb (Fig. 1).

The diagnostic aids used were: lateriomedial radiographs of the hooves, showing a loss of the phalanx axis and a bone remodeling of the third phalanx in the four limbs (Fig. 2). Blood samples are also taken for a blood count and blood biochemistry test (triglycerides $25 \mathrm{mg} / \mathrm{dL}$ and T4 $1.24 \mathrm{mg} / \mathrm{dL})$. 


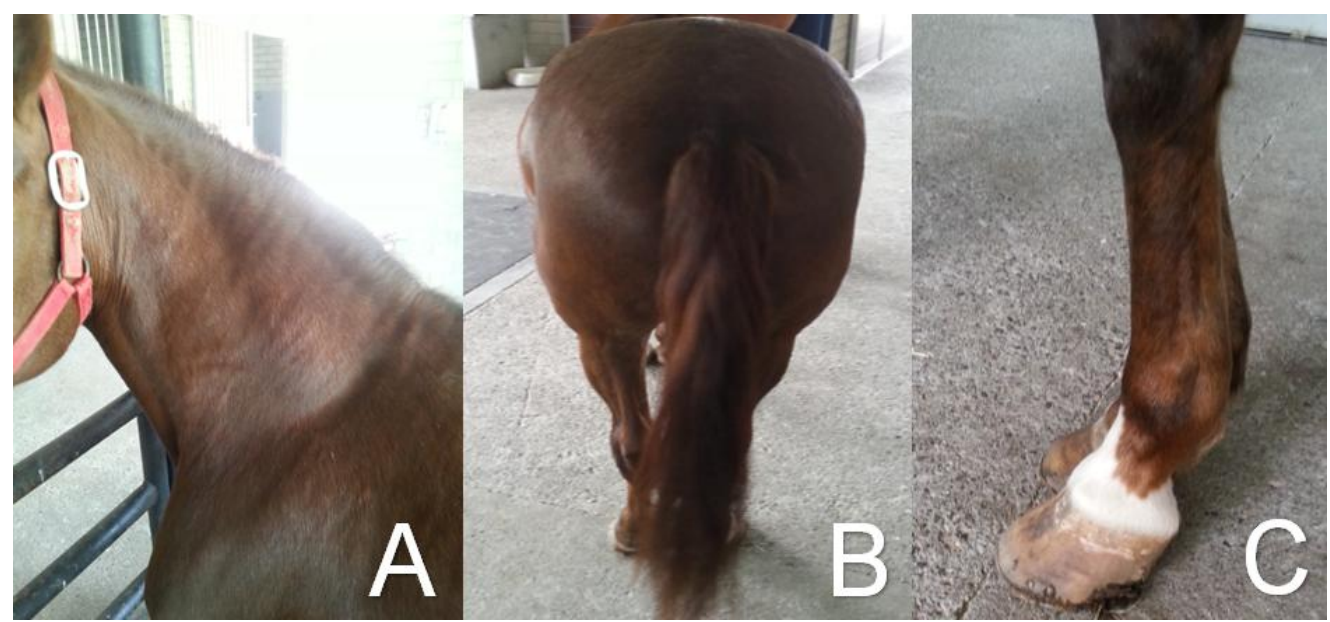

Figure 1. Obesity and chronic laminitis in a SME case. A, located adiposity; B, adiposity in the gluteal region and the perineum; $\mathrm{C}$, concentric rings in hooves.

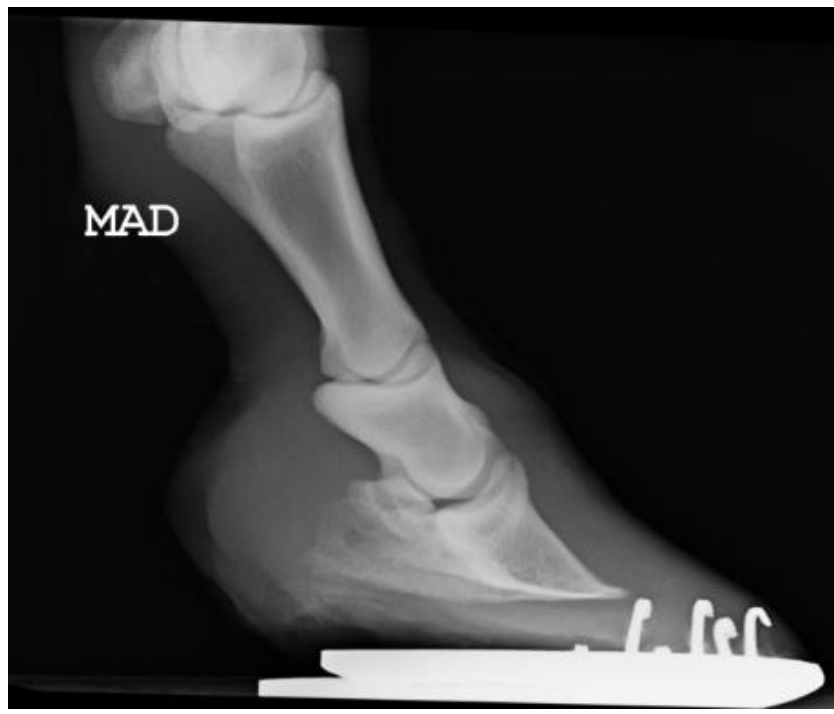

Figure 2. Lateromedial radiograph of a hoof, in which a loss of the phalanx axis and a bone remodeling of the third phalanx can be seen.

To confirm the diagnosis, the combined insulin and glucose test was performed, with 24 hours on an empty stomach before the test took place and, later, a jugular intravenous catheter was introduced $(14 \mathrm{G})$ in order to administer $150 \mathrm{mg} / \mathrm{kg}$ of dextrose at $50 \%$ and, immediately, $0,10 \mu / \mathrm{kg}$ of crystalline insulin (minute 0 ).
Baseline samples were taken to measure glucose and insulin and, later, glucose measurements were made in after $1,5,15,25,35,45,60$ and 75 minutes. In the $45^{\text {th }}$ minute a second sample was taken to measure insulin, with the results shown on Table 1:

Table 1. Results of measuring glucose in the combined glucose and insulin test

\begin{tabular}{|l|l|l|l|l|l|l|l|l|l|}
\hline $\begin{array}{l}\text { Time } \\
\text { (minutes) }\end{array}$ & 0 & 1 & 5 & 15 & 25 & 35 & 45 & 60 & 75 \\
\hline $\begin{array}{l}\text { Glucose } \\
\text { mg/dl }\end{array}$ & 96 & 233 & 205 & 125 & 85 & 70 & 38 & 20 & 10 \\
\hline
\end{tabular}


The glycemia curve was normal in the mare, as after insulin was given the glycemia levels got lower and it was necessary to administrate, intravenously, $120 \mathrm{~mL}$ of glucose at $50 \%$ diluted in a polyelectrolyte solution in order to reestablish the glycemia.

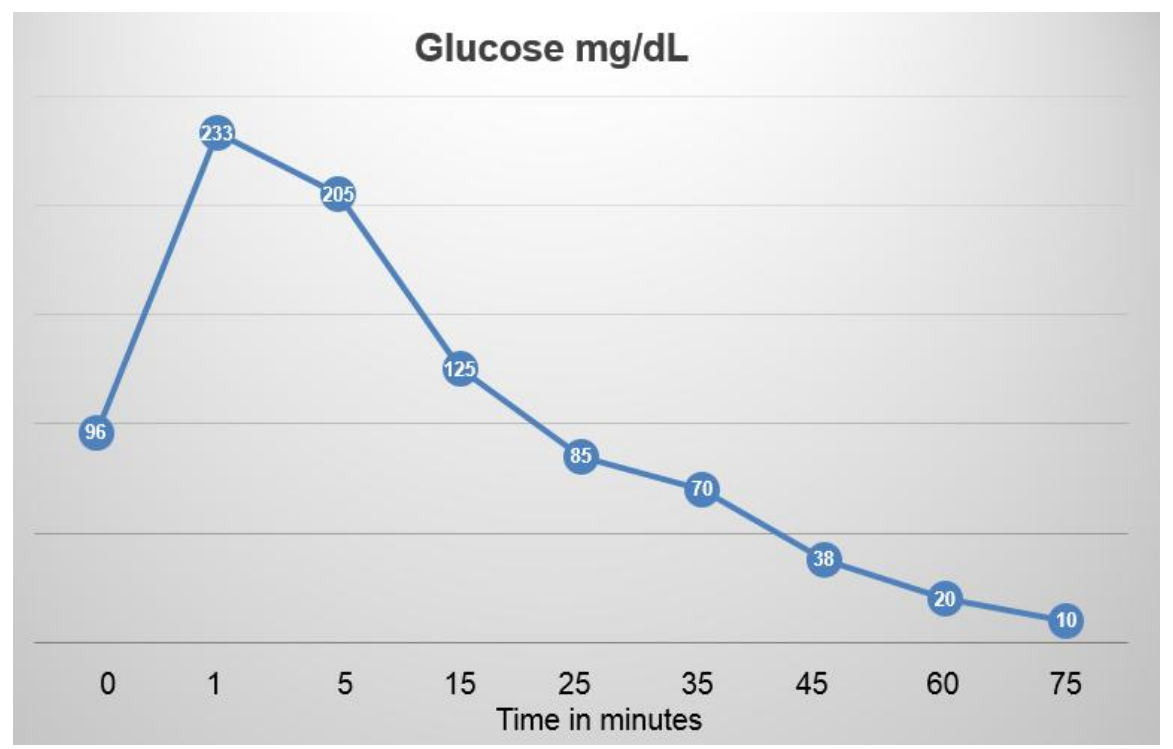

Figure 3. Glycemia curve of the combined glucose and insulin test. It can be seen how the glucose lowering after the administration of insulin.

The insulin baseline was $17.4 \mu \mathrm{IU} / \mathrm{mL}$ and after 45 minutes it was $308.9 \mu \mathrm{IU} / \mathrm{mL}$. The latter value demonstrated a considerable hyperinsulinemia, thus confirming the diagnosis of metabolic syndrome, added to the results of the physical test performed to the animal.

When the diagnosis was confirmed, the following therapy plan was established: Levothyroxine sodium, with doses of $0.1 \mathrm{mg} / \mathrm{kg}$ SID PO for three months and, finally, $0.05 \mathrm{mg} / \mathrm{kg}$ SID PO for two more weeks. The only food allowed was hay, reaching $2 \%$ of the body weight and an increase of the exercise to up to two hours a day was ordered, basically consisting in walking with the mare. The mare lost $48 \mathrm{~kg}$ during the treatment, improving its initial condition. It was recommended to keep the continuous exercise and not use concentrates to feed the mare.

\section{DISCUSSION AND CONCLUSIONS}

The mare meets the description of a patient with EMS (located adiposity, a high body condition, concentric rings in the hooves, bone remodeling at the third phalanges). Like some patients with SME, this mare had hematological and blood chemistry values within normal ratios; the triglycerides and the free $\mathrm{T} 4$ are measured in the patient in order to discard a dyslipemia or any other metabolic disturbance, and those values were also within the ratios, probably as a compensation mechanism.

The combined test of glucose and insulin was chosen for the diagnosis of this mare as it is considered the gold standard to diagnose EMS. The protocol was followed according Frank's indications (2011). The patient kept a hyperinsulinemia $(308.9 \mu \mathrm{U} / \mathrm{mL})$ until the 45 th minute after the test, a fact that indicates that more insulin is being freed (endogenously) and that the metabolism ratio is very slow, confirming RI and the EMS condition (Carter, 2009).

Part of the treatment for SME includes a diet and an exercise plan. The diet is based on reducing the energetic offer, favoring the reduction of the glycemia and the insulin's response to the food. Besides, the reduction of the digestible energy favors the weight loss in horses subjected to this regime, and this could be seen in the case of this mare (Frank, 2009). The controlled exercise not only favors weight loss, but also improves the 
sensibility to insulin. This was demonstrated in ponies subjected to treadmills up to six weeks after the treatment (Freestone et al. 1992).

As a pharmacological treatment, levothyroxine sodium, administered orally, was chosen. It is an analogical synthetic drug of thyroid hormones and it is basically used to improve the base line metabolism, reducing the animal's weight. Besides, it has been demonstrated that this drug favors the sensibility to respond to insulin. Signs of overdose, such as sweating, weakness, tachycardia or tachypnea were not seen in the patient, in fact they rarely occurred (Frank, 2005).

Other options of pharmacological treatment for EMS are the use of metformin, an antihypeglycemic used in horses that increases the sensibility to insulin (15mg/kg SID PO). Nevertheless, other authors reported inefficiency of this drug and this is why it was not used for this mare (Tinworth et al., 2012).

So far, this is the first scientific report of a case of a Colombian creole horse with EMS, using the best aids available as reported in the literature. Due to the fact that the diagnosis was made given the increase at the $45^{\text {th }}$ minute after insulin was administered, it is important to make specific studies for this breed. The conclusion is that every time a Colombian creole horse with located adiposity, laminitis and an adiposity ratio above 4 in the neck is received, EMS must be considered within the differential diagnoses.

\section{ACKNOWLEDGEMENTS}

We will like to express our gratitude to the Dean of the Faculty of Administrative and Agriculture Sciencie, Cristhian Cabra. And to the Research Vice-Presidency Luis Fernando Garcéz Giraldo, from the Corporación Universitaria Lasallista for the financial support of this work.

\section{REFERENCES}

BERTIN, F.; SOJKA-KRITCHEVSKY, J. Comparison of a 2-step insulin-response test to conventional insulin-sensitivity testing in horses. Domest. Anim. Endocrinol., v.44, p.19-25, 2013.
BURNS, T.; GEOR, R.; MUDGE, M.J. et al. Proinflammatory cytokine and chemokine gene expression profiles in subcutaneous and visceral adipose tissue depots of insulin-resistant and insulin-sensitive light breed horses. J. Vet. Intern. Med., v.24, p.932-939, 2010.

CARTER, R.A. Apparent adiposity assessed by standardised scoring systems and morphometric measurements in horses and ponies. Vet. J., v.179, p.204-210, 2009.

CASELLI, C. Role of adiponectin system in insulin resistance. Mol. Genet. Metab., v.113, p.155-160, 2014.

FRANK, N. Effects of oral administration of levothyroxine sodium on concentrations of plasma lipids, concentration and composition of very-low-density lipoproteins, and glucose dynamics in healthy adult mares. Am. J. Vet. Res., v.66, p.1032-1038, 2005

FRANK N. Equine metabolic síndrome. $J$. Equine Vet. Sci., v.29, p.259-267, 2009.

FRANK N. Equine metabolic syndrome. Vet. Clin. N. Am. Equine, v.27, p.73-92, 2011.

FREESTONE, J.F.; BEADLE, R.; SHOEMAKER, K. et al. Improved insulin sensitivity in hyperinsulinaemic ponies through physical conditioning and controlled feed intake. Equine Vet. J., v.24, p.187-190, 1992.

GEOR, R.; MCCUE, M.; SCHULTZ, N. Current understanding of the equine metabolic síndrome phenotype. J. Equine Vet. Sci.,v.33, p.841-843, 2013.

MARYCZ, K.; BASINSKA, K.; TOKER, N. et $a l$. The activity of IL- 6 and TNF- $\alpha$ in adipose tissue and peripheral blood in horses suffering from equine metabolic síndrome (EMS). Kafkas Univ. Vet. Fak. Derg., v.20, p.493-499, 2014.

SESTI, G. Pathophysiology of insulin resistance. Best Pract. Res. Clin. Endocrinol. Metab., v.20, p.665-679, 2006.

TINWORTH, K.D.; BOSTON, R.C.; HARRIS, P.A. et al. The effect of oral metformin on insulin sensitivity in insulin-resistant ponies. Vet. J., v.191, p.79-84, 2012. 